\title{
Threatened fishes of the world: Luciobarbus subquincunciatus (Günther, 1868) (Cyprinidae)
}

\author{
Brian W. Coad
}

Received: 25 February 2009 / Accepted: 14 July 2009 / Published online: 28 July 2009

(C) Springer Science + Business Media B.V. 2009

Common name: abou khazzama, a'djzan, nabish (Arabic), solimani, sos mahi (Farsi), bıyıklı balık, komando balığ 1 , benekli barbus (Turkish); leopard barbel, spot barb, Mesopotamian barbel (E). Conservation status: Extirpated in the southern marshes of Iraq (Italy-Iraq 2006); almost disappeared in Syria (FAO 2007); rare in Turkish Tigris (Ünlü 2006); occasional in commercial catches in Iran, only six fish caught in 1990s, "critically endangered" (M. Ramin, personal communication 2000). Identification: Originally described in Barbus. Uniquely characterised by the quincunx-like pattern of spots. Branched dorsal fin rays 8 , branched anal fin rays 5, lateral line scales 75-88. Inner pharyngeal teeth molariform, formula 2,3,3-3,3,2. Maximum length $60 \mathrm{~cm}$. Illustration by Susan Laurie-Bourque. Distribution: Found in the Tigris-Euphrates basin of Turkey, Syria, Iraq and Iran. Habitat and ecology: Favours lentic, high oxygen habitats but may occur in reservoirs. Molluscivore based on teeth but also takes algae and detritus. Reproduction: Spawns in shallow gravel beds in April-May in Turkish Tigris River (Ünlü 2006). Threats: Use as food, habitat loss, eutrophication, dam construction and water abstraction. Conservation

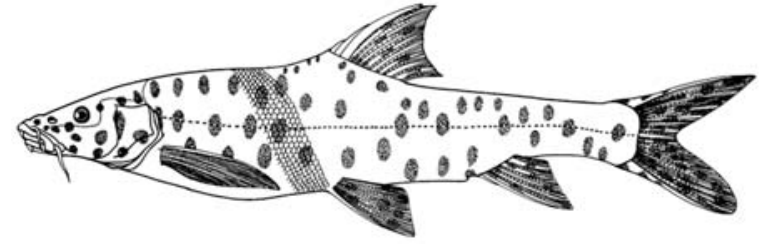

actions: Adults so rare in Iran aquaculture not feasible and fish released. Conservation recommendations: Surveys to determine spawning sites for protection.

\section{References}

FAO (2007) Fishery country profile. The Syrian Arab Republic. Food and Agriculture Organization, Rome. FID/CP/SYR, $14 \mathrm{pp}$

Italy-Iraq (2006) New Eden Master Plan for Integrated Water Resources Management in the Marshlands Area, Volume 1, Overview of present conditions and current use of the water in the marshlands area, Book 4, Marshlands. The Italian Ministry for the Environment and Territory and Free Iraq Foundation. 278 pp

Ünlü E (2006) Tigris River ichthyological studies in Turkey. A review with regard to the Ilisu Hydroelectric Project. Ilisu Consortium, Turkey. $34 \mathrm{pp}$

B. W. Coad $(\bowtie)$

Canadian Museum of Nature,

P. O. Box 3443, Station D,

Ottawa, ON K1P 6P4, Canada

e-mail: bcoad@mus-nature.ca 